Vol 2, No 1, Juni 2021; 1-17

e-ISSN : 2723-3324

Available at: e-journal.sttberitahidup.ac.id/index.php/jan/index

\title{
Role Model Kepemimpinan Transformasional Berdasarkan 2 Raja-raja 18:1-8 pada Borneo Evangelical Mission Sarawak
}

\author{
Welly Sigo ${ }^{1}$ \\ wellyswualn377@gmail.com
}

\begin{abstract}
The leadership factor greatly determines the progress and success of an organization. During the same period as the Borneo Evangelical Mission (BEM) Synod, which has reached 93 years this year. It was time for BEM to evaluate existing leadership, both related to institutionalization, administrative systems and service programs. This research is a qualitative research with historical and phenomenological analysis, which uses observation, documentation, and interview techniques. The data analysis model used is descriptive analysis using the perspective of Christian leadership to find a suitable model for future BEM leaders. The purpose of this study was to determine the role model of transformational leadership based on biblical principles taken from 2 Kings 18: 1-8 to become a role model for the leadership of BEM Sarawak, especially in every level at the central and regional levels. Of course this research will also indirectly impress the leadership in the rankings of local churches and ministries that are available in BEM Sarawak. This study aims to find the principles of biblical leadership practice, and to provide answers to biblical principles for leaders and congregations to continue to play an active role in the ministry through the opportunities God has given them. Practically the results of this research can help the leaders of BEM Sarawak to lead the congregation to mobilize all congregations to become involved as channels of God's love to this world.
\end{abstract}

Keywords: transformational; role models; 2 Kings 18:1-8; vision and competence

\begin{abstract}
Abstrak
Faktor kepemimpinan sangat menentukan kemajuan dan keberhasilan sebuah organisasi. Selama kurun waktu bersamaan dengan usia Sinode Borneo Evangelical Mission (BEM) yang sudah mencapai 93 tahun pada tahun ini. Tiba masanya untuk BEM melakukan evaluasi terhadap kepemimpinan yang ada, baik yang berkaitan dengan pelembagaan, sistem administrasi dan program pelayanan. Penelitian ini merupakan penelitian kualitatif dengan analisis historis dan fenomenologi, yang menggunakan teknik observasi, dokumentasi, dan wawancara. Model analisis data yang digunakan ialah analisis deskriptif dengan menggunakan perspektif kepemimpinan Kristen untuk menemukan model yang sesuai bagi pemimpin BEM akan datang. Tujuan penelitian ini adalah untuk mengetahui Role Model kepemimpinan transformasional berdasarkan prinsip Alkitab yang diambil dari 2 Raja-Raja 18:1-8 menjadi role model bagi kepemimpinan BEM Sarawak khususnya di setiap peringkat di pusat dan daerah. Sudah tentu penelitian ini juga secara tidak langsung akan memberi
\end{abstract}

\footnotetext{
${ }^{1}$ Mahasiswa Doktoral Sekolah Tinggi Teologi Berita Hidup
} 
kesan kepada kepemimpinan di peringkat gereja-gereja lokal dan bidang-bidang pelayanan yang sedia ada di dalam BEM Sarawak. Penelitian ini bertujuan menemukan prinsip-prinsip pelaksanaan kepemimpinan yang Alkitabiah, dan memberi jawaban terhadap prinsip Alkitabiah kepada pemimpin dan jemaat agar tetap berperan aktif di dalam pelayanan melalui kesempatan yang Tuhan anugerahkan. Secara praktis hasil penelitian ini dapat membantu para pemimpin BEM Sarawak untuk memimpin jemaat untuk mengerakkan semua jemaat untuk terlibat menjadi saluran kasih Allah kepada dunia ini.

Kata Kunci: transformasional; role model; 2 Raja-raja 18:1-8; visi dan kompetensi

\section{PENDAHULUAN}

Ketika memasuki milenium ketiga, dunia kepemimpinan sekuler dan Kristen telah banyak mengalami transformasi, bahkan terjadi perubahan nilai-nilai yang seharusnya dipertahankan sesuai dengan kebenaran Alkitab. Prinsip-prinsip dan praktik kepemimpinan Kristen telah mengadaptasi gaya dan prinsip kepemimpinan sekuler sehingga terjadi pergeseran makna dan nilai-nilai kepemimpinan sehingga mengakibatkan terjadinya banyak kompromi-kompromi dari pemimpin-pemimpin Kristen dengan dosa-dosa dunia dan moral yang rusak. Tidak dapat dinafikan bahwa gereja BEM pada hari ini berada di era yang menuntut perubahan dalam berbagai aspek seperti, corak kepemimpinan, sistem administrasi, pindaan pelembagaan dan lain-lain. Meskipun perubahan perlu dilakukan namun perlu dipertimbangkan dan menjadi asas kebijakan adalah kehendak Tuhan dan bukan kehendak pemimpin. Hal ini dijelaskan oleh Y. Tomatala:

"Kepemimpinan Kristen adalah suatu proses terencana yang dinamis dalam konteks pelayanan Kristen (yang menyangkut faktor waktu, tempat, dan situasi khusus) yang di dalamnya oleh tuntunan Allah, Ia memanggil bagi diri-Nya seorang pemimpin dengan kapasitas penuh untuk pemimpin umat-Nya (yang mengelompokkan diri dalam situasi atau organisasi), guna mencapai tujuan Allah yang membawa keuntungan bagi pemimpin, bawahan, dan lingkungan hidup serta melalui umat-Nya, untuk kekayaan kerajaan-Nya."2

Seharusnya sebagai pemimpin Kristen perlu sadar bahwa sebagai pemimpin tidak boleh melaksanakan dan menentukan kebijakan terlepas dari rencana Allah. Program yang dirancang pemimpin dapat berjalan dengan baik, dan proses kepemimpinannya tidak merugikan, tetapi menguntungkan baik pemimpin maupun bawahan. Kepemimpinan Kristen didasarkan pada premis utama, yaitu bahwa Allah yang oleh kehendak-Nya yang berdaulat, telah menetapkan serta memilih setiap pemimpin Kristen untuk melakukan pelayanan dalam konteks kepemimpinan. Ken Blanchard dan Phil Hodges menjelaskan:

${ }^{2}$ Yakob Tomatala, Mencari Format Kepemimpinan Gereja yang Kontekstual di Indonesia (Jakarta: YT Leadership Foundation, 2002), 12. 
Bagi para pengikut Yesus, kepemimpinan sebagai tindakan pelayanan bukanlah pilihan. Itu adalah mandat atau perintah. Kepemimpinan yang melayani harus menjadi pernyataan hidup dari mereka yang tinggal dalam Kristus, cara kita memperlakukan satu sama lain, dan cara kita memperlihatkan cinta Kristus kepada seluruh dunia. ${ }^{3}$

Paradigma yang murni dari Alkitab sebenarnya telah diadaptasi oleh kepemimpinan sekuler di abad-abad reformasi telah berbalik menjadi percampuran pemimpin Kristen dengan prinsip kepemimpinan sekuler yang berorientasi pada budaya dan pandangan hidup pasca-modern. Kebenaran dalam kepemimpinan Kristen telah beralih dari Alkitab kepada sinkretisme prinsip kepemimpinan yang tidak mencerminkan Kekristenan dan nilai-nilai luhur dari kepemimpinan yang Alkitabiah. Kondisi ini sangatlah serius di mana pemimpinpemimpin ini hanya berusaha menyenangkan hati pengikut dan dunia di sekitar untuk memperoleh pengakuan dan keamanan. Oleh sebab itu terjadilah banyak pelanggaranpelanggaran moral pemimpin-pemimpin Kristen karena orientasi bukanlah kebenaran tetapi materi, kemewahan dan terutama paham dari ajaran kemakmuran yang tumbuh subur di negara-negara Barat dan Timur. Humanisme dikaitkan dengan prinsip-prinsip ini sehingga pemimpin-pemimpin mendapatkan kesempatan dan keuntungan untuk mengait keuntungan pribadi dari jabatan dan panggilan yang telah dipercayakan oleh Allah. Peter Scazzero melihat hal ini sebagai masalah batin yang harus dibenahi seperti yang diungkapkan dalam bukunya:

Pemimpin gereja, organisasi, atau pelayanan yang mengubah dunia butuh lebih dari sekadar strategi dan teknik kepemimpinan terkini. Perubahan yang bertahan dalam gereja dan organisasi membutuhkan pria dan wanita yang berkomitmen untuk memimpin melalui kehidupan batin yang dalam dan diubahkan. ${ }^{4}$

Dalam tulisan ini, prinsip-prinsip dalam model kepemimpinan Perjanjian Lama, khususnya kepemimpinan berdasarkan Kitab 2 Raja-Raja 18 merefleksi dan membangun kembali fondasi kepemimpinan Kristen berdasarkan kepemimpinan Raja Hizkia. Prinsip dan model kepemimpinan Raja Hizkia merupakan sebuah alat filter untuk memulihkan kehidupan kepemimpinan Kristen di era pasca-modern yang telah menyimpang dari kebenaran Allah. Oleh sebab itu perlu dikritisi bahwa kepemimpinan 2 Raja-Raja 18 merupakan uraian kepemimpinan Alkitabiah dan dipraktikkan dalam kepemimpinan pemerintahan Israel dan Yehuda.

Landasan kepemimpinan Raja Hizkia bagi kepemimpinan masa kini khususnya di kalangan pemimpin BEM adalah sangat signifikan apabila Kekristenan ingin bertumbuh

\footnotetext{
${ }^{3}$ Ken Blanchard dan Phil Hodges, Lead Like Jesus (Tangerang: Visi Media, 2006), 15.

${ }^{4}$ Peter Scazzero, The Emotionallly Healthy Leader (Surabaya: Perkantas, 2018), 50.
} 
dalam institusi atau lembaga maupun dalam masyarakat majemuk, bukan untuk meniru tetapi untuk membawa pengaruh positif bagi pengikut-pengikut dan bagi dunia sekitarnya. Hakikatnya kepemimpinan BEM perlu membuat perubahan agar menjadi gereja yang relevan sebagai salah satu instrumen dalam melaksanakan rencana Allah di dunia dan khususnya di Malaysia.

\section{METODE}

Metode dalam penelitian ini adalah kualitatif dengan analisis historis dan fenomenologi, yang menggunakan data primer dan data sekunder. Dalam pengumpulan data, peneliti menggunakan teknik observasi, dokumentasi, dan wawancara. Model analisis data yang digunakan ialah analisis deskriptif dengan menggunakan perspektif kepemimpinan Kristen. Yaitu suatu teori yang berasaskan kajian teologi untuk menemukan model yang sesuai bagi pemimpin BEM akan datang.

\section{HASIL DAN PEMBAHASAN}

\section{Sejarah Kepemimpinan Borneo Evangelical Mission (BEM)}

Borneo Evangelical Mission (BEM) adalah sebuah Denominasi Gereja Injili yang ahlinya kebanyakan dari kalangan masyarakat Orang Ulu di Borneo, dan khususnya di Sarawak-Malaysia. Ia ditubuhkan pada Oktober 1928 oleh tiga orang misionaris yang berasal dari Australia yaitu Hudson Southwell, Frank Davidson dan Carey Tolley. Pada tahun 1975 BEM bergabung dengan Fellowship Fellowship Luar Negara (dahulunya China Inland Mission). Borneo Evangelical Mission (BEM) telah didirikan oleh tiga orang misionaris di atas melalui perjalanan misi menaiki kapal pengangkut kargo lama dari Melbourne pada awal Oktober 1928 ke Singapura. Bersama di dalam rombongan misi tersebut adalah Alexander Henderson, seorang perintis perdagangan kayu balak Asia Tenggara yang menawarkan untuk membantu mendirikan pos di pulau Borneo.

Pada 12 November 1928, Southwell dan Henderson mendarat di Kuching, Borneo. Pada masa tersebut Borneo dijajah oleh Raja British yaitu Charles Vyner Brooke. Beliaulah yang memberi kebenaran untuk membangun sebuah misi di Sarawak dan menyarankan untuk memulai di kawasan Limbang ke Utara sebelah Timur. Di kemudian hari Davidson dan Tolley menyertai mereka. Sarawak bersama-sama dengan Sabah dan Persekutuan Tanah Melayu bergabung dan membentuk Malaysia pada tahun 1963. Dengan peningkatan penggunaan bahasa Malaysia sebagai bahasa Kebangsaan maka Borneo Evangelical Mission (BEM) telah diterjemahkan menjadi Sidang Injil Borneo (SIB). Hari ini, gereja-gereja SIB 
bisa ditemukan di Sarawak, Sabah dan Semenanjung Malaysia dan telah mengalami perkembangan yang begitu pesat baik secara fisika dan bilangan anggotanya. ${ }^{5}$

Peneliti akan menyajikan penelitian kepemimpinan transformasional berdasarkan 2 Raja-Raja 18:1-8 sebagai landasan kepemimpinan dan role model bagi para pemimpin BEM Sarawak, sesuai dengan subfokus penelitian 2 Raja-Raja 18:1-8 yaitu pemimpin yang berintegritas, pemimpin yang beriman, pemimpin yang taat dan pemimpin yang kompeten. Bagi memastikan keakuratan data penelitian, peneliti telah mewawancara para pemimpin BEM selaku informan.

\section{Hasil Wawancara}

Subfokus 1: Ciri-ciri Pemimpin Berdasarkan 2 Raja-Raja 18 :1-8

\begin{tabular}{|c|l|}
\hline \multicolumn{2}{|l|}{ Seperti apakah ciri-ciri seorang pemimpin yang diperlukan di dalam BEM? } \\
\hline Informan & Jawaban \\
\hline 1 & $\begin{array}{l}\text { Menjadi seorang pemimpin yang 'to lead to self' sehingga kita mampu } \\
\text { menyesuaikan diri dengan sesiapa saja. }\end{array}$ \\
\hline 2 & $\begin{array}{l}\text { Seorang pemimpin yang dipilih Tuhan, mempunyai intimasi dengan Tuhan } \\
\text { dan mempunyai gaya kepemimpinan servant leadership. }\end{array}$ \\
\hline 3 & $\begin{array}{l}\text { Pemimpin perlu tahu apa yang ingin dia lakukan, ini bercakap tentang visi } \\
\text { dan misi dia. }\end{array}$ \\
\hline 4 & $\begin{array}{l}\text { Seorang yang mampu melihat yang hendak dicapai dan mudah untuk } \\
\text { diikuti }\end{array}$ \\
\hline 5 & $\begin{array}{l}\text { Seorang yang hidup di bawah pimpinan Tuhan, proaktif dan mampu } \\
\text { menjangkakan keadaan pada masa akan datang }\end{array}$ \\
\hline 6 & $\begin{array}{l}\text { Seorang pemimpin haruslah seorang yang berkarisma dan mampu } \\
\text { mengimplementasikan tugas sebagai pemimpin. }\end{array}$ \\
\hline
\end{tabular}

Berdasarkan hasil wawancara dengan informan mengenai pertanyaan seperti apakah ciri-ciri seorang pemimpin yang diperlukan di dalam BEM? Peneliti menemukan dua informan berpandangan bahwa ciri seorang pemimpin yang diperlukan di dalam BEM adalah pemimpin yang dipilih oleh Tuhan. Dua lagi informan berpandangan bahwa ciri pemimpin yang diperlukan BEM adalah seorang yang memiliki visi. Seorang informan berpandangan bahwa ciri pemimpin yang diperlukan BEM adalah pemimpin yang berhati hamba, manakala menurut informan berpendapat bahwa ciri pemimpin BEM akan datang

5 “Borneo Evangelical Mission," last modified 2019, diakses Januari 31, 2021, https://en.wikipedia.org/wiki/Borneo_Evangelical_Mission. 
adalah seorang yang berkarisma dan mampu mengimplementasikan tugas sebagai pemimpin.

\begin{tabular}{|c|l|}
\hline \multicolumn{2}{|c|}{ Apakah seorang pemimpin perlu membuat perubahan dalam masa jabatannya? } \\
\hline Informan & Jawaban \\
\hline 1 & $\begin{array}{l}\text { Mau tidak mau seorang pemimpin harus membuat perubahan baik secara } \\
\text { rohani dan fisikal atau dalam kata lain secara holistik untuk mengembalikan } \\
\text { BEM kepada panggilan Tuhan yang sebenarnya. }\end{array}$ \\
\hline 2 & $\begin{array}{l}\text { Sangat perlu membuat perubahan jika tidak maka seorang pemimpin itu } \\
\text { hanya melaksanakan tanggung jawab sebagai rutinitas. }\end{array}$ \\
\hline 3 & Ya dia perlu mengenal pasti keadaan dan tahu apa yang perlu dilakukan. \\
\hline 4 & $\begin{array}{l}\text { Tidak perlu perubahan, melainkan kita hanya perlu memperbaiki yang tidak } \\
\text { relevan yaitu kebajikan para hamba Tuhan yang melayani secara penuh } \\
\text { masa di BEM }\end{array}$ \\
\hline 5 & $\begin{array}{l}\text { Situasi tidak berubah namun pemimpin perlu berubah dan memerlukan } \\
\text { hikmat daripada Tuhan. }\end{array}$ \\
\hline 6 & $\begin{array}{l}\text { Tidak banyak perubahan yang perlu dilakukan, namun pemimpin harus } \\
\text { bersikap terbuka untuk melakukan perubahan. }\end{array}$ \\
\hline
\end{tabular}

Berdasarkan hasil wawancara dengan informan mengenai pertanyaan apakah seorang Pemimpin BEM perlu membuat perubahan di dalam masa jabatannya? Bagi pertanyaan ini peneliti temukan bahwa 5 orang setuju bahwa perubahan itu perlu atau harus dilakukan meskipun tujuan dari perubahan itu dilakukan memberi jawaban yang berbeda-beda. Mana kala seorang informan berpandangan bahwa perubahan tidak perlu dilakukan dan apa yang perlu adalah memperbaiki yang tidak relevan.

\section{Subfokus 2: Role Model Kepemimpinan Raja Hizkia Berdasarkan 2 Raja-Raja 18 :1-8}

Sebelum membentangkan hasil temuan ini, terlebih dahulu peneliti perlu menunjukkan hasil mengenai akibat bagi pemimpin BEM jika tidak menjadi role model sebagai pemimpin yang ditemukan melalui penelitian dengan menggunakan analisis komponen.

\section{Pertanyaan analisis komponen}

\begin{tabular}{|c|l|}
\hline \multicolumn{2}{|l|}{$\begin{array}{l}\text { Apakah akibatnya jika seorang pemimpin tidak dapat menjadi role model sebagai } \\
\text { pemimpin? }\end{array}$} \\
\hline Informan & Jawaban \\
\hline 1 & $\begin{array}{l}\text { Pemimpin yang tidak mampu menjadi model sudah tentu tidak dapat } \\
\text { membawa perubahan kepada jemaat. Sebab sebagai pemimpin semua orang } \\
\text { akan melihat kita. }\end{array}$ \\
\hline
\end{tabular}




\begin{tabular}{|c|l|}
\hline 2 & $\begin{array}{l}\text { Seorang pemimpin yang tidak dapat menjadi model dia tidak akan } \\
\text { berkembang di dalam pelayanannya. Sebab pemimpin bercakap mengenai } \\
\text { bagaimana untuk mencapai gol yang ingin dicapai. Ini memerlukan upaya } \\
\text { untuk membawa orang lain. Orang yang kita pimpin tidak akan mengikuti } \\
\text { apa yang kita cakap jika kita sebagai pemimpin tidak mampu menjadi } \\
\text { model. Keadaan inilah yang menyebabkan pelayanan seorang pemimpin } \\
\text { tidak berkembang. }\end{array}$ \\
\hline 3 & $\begin{array}{l}\text { Pemimpin itu akan kehilangan wewenangnya jika dia tidak dapat menjadi } \\
\text { model, karena pemimpin harus menjadi contoh kepada jemaat. }\end{array}$ \\
\hline 4 & $\begin{array}{l}\text { Masing-masing pemimpin pasti ada kekuatan dan kelemahan. Dalam hal ini } \\
\text { pemimpin harus bersikap terbuka dan bersedia untuk berubah. }\end{array}$ \\
\hline 5 & $\begin{array}{l}\text { Setiap pemimpin pasti ada kelemahan dan kekurangannya. Namun sebagai } \\
\text { pemimpin perlu ada kepekaan untuk memahami keadaan dan apa yang akan } \\
\text { berlaku. }\end{array}$ \\
\hline 6 & $\begin{array}{l}\text { Jika seseorang pemimpin melakukan kesalahan kita tidak boleh menghakimi } \\
\text { seseorang karena satu kelemahannya. Ini yang Firman Tuhan ajarkan } \\
\text { kepada kita. }\end{array}$ \\
\hline
\end{tabular}

Temuan bagi pertanyaan dari 6 orang informan dengan pertanyaan, "Apakah akibatnya jika seorang pemimpin tidak dapat menjadi model sebagai pemimpin?” Jawaban bagi pertanyaan ini mendapati berbagai respons dari informan. Satu orang menjawab pemimpin yang tidak mampu menjadi model sudah tentu tidak dapat membawa perubahan kepada jemaat. Sebab sebagai pemimpin semua orang akan melihat kita. Satu orang informan berpendapat bahwa seorang pemimpin yang tidak dapat menjadi model dia tidak akan berkembang di dalam pelayanannya. Sebab pemimpin berbicara mengenai bagaimana untuk mencapai gol yang ingin dicapai. Ini memerlukan upaya untuk membawa orang lain. Orang yang kita pimpin tidak akan mengikuti apa yang kita katakan jika kita sebagai pemimpin tidak mampu menjadi model. Keadaan inilah yang menyebabkan pelayanan seorang pemimpin tidak berkembang. Satu orang informan berpendapat bahwa pemimpin itu akan kehilangan wewenangnya jika dia tidak dapat menjadi model karena pemimpin harus menjadi contoh kepada jemaat. Masing-masing pemimpin pasti ada kekuatan dan kelemahan. Satu orang informan menjelaskan, dalam hal ini pemimpin harus bersikap terbuka dan bersedia untuk berubah. Satu orang informan berpendapat bahwa setiap pemimpin pasti ada kelemahan dan kekurangannya. Namun sebagai pemimpin perlu ada kepekaan untuk memahami keadaan dan apa yang akan berlaku. Satu orang informan menjelaskan bahwa setiap pemimpin pasti ada kelemahan dan kekurangannya. Namun sebagai pemimpin perlu ada kepekaan untuk memahami keadaan dan apa yang akan berlaku. Dan satu orang lagi informan berpendapat jika seseorang pemimpin melakukan kesalahan 
kita tidak boleh menghakimi seseorang karena satu kelemahannya. Ini yang Firman Tuhan ajarkan kepada kita.

Pertanyaan analisis taksonomi

\begin{tabular}{|c|l|}
\hline \multicolumn{2}{|l|}{ Bagaimana karakter pemimpin yang menjadi role model? } \\
\hline Informan & Jawaban \\
\hline 1 & Pemimpin yang berhati hamba \\
\hline 2 & $\begin{array}{l}\text { Pemimpin yang siap membayar harga dan bergerak senafas dengan rencana } \\
\text { Allah }\end{array}$ \\
\hline 3 & Pemimpin yang memiliki visi dari Tuhan \\
\hline 4 & Seorang yang hidup sesuai dengan kehendak Tuhan \\
\hline 5 & $\begin{array}{l}\text { Pemimpin yang tunduk dan mengikuti Kristus sebagai Kepala kita yang } \\
\text { Maha mengetahui. }\end{array}$ \\
\hline 6 & Seorang dipanggil Tuhan untuk menjadi pemimpin \\
\hline
\end{tabular}

Temuan bagi pertanyaan dari 6 orang informan terkait dengan pertanyaan, "Bagaimana karakter pemimpin yang menjadi role model?" Jawaban bagi pertanyaan ini mendapati berbagai respons dari informan di mana empat informan berpendapat bahwa karakter pemimpin yang menjadi model adalah pemimpin yang tunduk kepada Tuhan sebagai sumber otoritas. Seorang berpendapat bahwa karakter pemimpin yang menjadi role model adalah pemimpin yang memiliki visi dari Tuhan dan satu orang lagi menjawab bahwa pemimpin adalah seorang yang dipanggil Tuhan untuk menjadi pemimpin.

\section{Pertanyaan dengan analisis komponen}

\begin{tabular}{|c|l|}
\hline \multicolumn{2}{|l|}{ Apakah akibatnya jika seorang pemimpin tidak mau berubah? } \\
\hline Informan & Jawaban \\
\hline 1 & $\begin{array}{l}\text { Jika seorang pemimpin tidak mau berubah maka perubahan tidak akan } \\
\text { berlaku pada saat dia memimpin. }\end{array}$ \\
\hline 2 & $\begin{array}{l}\text { Pemimpin yang tidak mau berubah tidak akan berkembang dan merupakan } \\
\text { maintanance leadership. }\end{array}$ \\
\hline 3 & $\begin{array}{l}\text { Jika pemimpin tidak mau berubah maka tidak akan ada kesinambungan } \\
\text { perubahan. }\end{array}$ \\
\hline 4 & $\begin{array}{l}\text { Mau tidak mau seorang pemimpin harus melakukan perubahan jika tidak } \\
\text { maka dia akan ketinggalan zaman }\end{array}$ \\
\hline 5 & Jika dunia tidak berubah maka seorang pemimpinlah yang perlu berubah. \\
\hline 6 & $\begin{array}{l}\text { Seorang pemimpin yang tidak mau berubah tidak akan dapat bersaing dengan } \\
\text { dunia yang ada di sekitarnya. }\end{array}$ \\
\hline
\end{tabular}


Temuan bagi pertanyaan dari 6 orang informan berikutan dengan pertanyaan “Apakah akibatnya jika seorang pemimpin tidak mau berubah?” Jawaban bagi pertanyaan ini mendapati setiap informan mempunyai jawaban masing-masing di mana informan 1 berpandangan bahwa jika seorang pemimpin tidak mau berubah maka perubahan tidak akan berlaku pada saat dia memimpin. Informan 2 menjawab pemimpin yang tidak mau berubah tidak akan berkembang dan merupakan maintenance leadership. Informan 3 berpendapat jika pemimpin tidak mau berubah maka tidak akan ada kesinambungan perubahan. Menurut informan 4 pula mau tidak mau seorang pemimpin harus melakukan perubahan jika tidak maka dia akan ketinggalan zaman. Informan 5 memberi jawaban yang cukup menarik yaitu jika dunia tidak berubah maka seorang pemimpinlah yang perlu berubah. Dan informan 6 berpendapat bahwa seorang pemimpin yang tidak mau berubah tidak akan dapat bersaing dengan dunia yang ada di sekitarnya.

Subfokus 3: Visi Kepemimpinan Raja Hizkia Berdasarkan 2 Raja-raja 18 :1-8

\begin{tabular}{|c|l|}
\hline \multicolumn{2}{|c|}{ Apakah para pemimpin melaksanakan visi berdasarkan kehendak Tuhan? } \\
\hline Informan & Jawaban \\
\hline 1 & $\begin{array}{l}\text { Sebagai seorang pemimpin harus menjadi sebahagian dari apa yang Tuhan } \\
\text { inginkan dalam masa jabatannya. }\end{array}$ \\
\hline 2 & $\begin{array}{l}\text { Seorang pemimpin harus “on the vision" oleh sebab itu dia perlu menjual } \\
\text { visi dalam erti mengkomunikasikan visi yang jelas sehingga visi itu menjadi } \\
\text { milik semua orang yang dipimpin. }\end{array}$ \\
\hline 3 & Visi haruslah berasal dari Allah. \\
\hline 4 & Perlu memiliki visi yang sesuai dengan kehendak Tuhan \\
\hline 5 & $\begin{array}{l}\text { Kunci seorang pemimpin adalah harus mempunyai visi dan mampu } \\
\text { mengkomunikasikannya kepada team. }\end{array}$ \\
\hline 6 & $\begin{array}{l}\text { Pemimpin harus melaksanakan tanggung jawab sesuai dengan sistem yang } \\
\text { ada. }\end{array}$ \\
\hline
\end{tabular}

Berdasarkan hasil wawancara dengan informan mengenai pertanyaan apakah para pemimpin melaksanakan visi berdasarkan kehendak Tuhan? Jawaban yang peneliti temukan adalah 3 informan sependapat bahwa seorang pemimpin harus memiliki visi yang daripada Tuhan. Dua lagi menjawab bahwa seorang pemimpin perlu ada visi dan mampu mengongsikan visi sebagai pemimpin. Sedangkan seorang lagi menjawab bahwa pemimpin harus melaksanakan tanggung jawab sesuai dengan sistem yang ada. 
Subfokus 4: Kepemimpinan Raja Hizkia yang Kompeten Berdasarkan 2 Raja-raja 18:1-8

\begin{tabular}{|c|l|}
\hline \multicolumn{2}{|l|}{$\begin{array}{l}\text { Bagaimanakah pemimpin hari ini dapat melakukan perubahan di dalam } \\
\text { kepemimpinannya? }\end{array}$} \\
\hline Informan & Jawaban \\
\hline 1 & $\begin{array}{l}\text { Seorang pemimpin perlu membuat analisis dan melihat keperluan tempat di } \\
\text { mana dia memimpin. Karena setiap tempat mempunyai keperluan yang } \\
\text { berbeda-beda. }\end{array}$ \\
\hline 2 & $\begin{array}{l}\text { Pemimpin itu adalah bermusim atau dalam istilah lain "regeneration". } \\
\text { Sebagai pemimpin yang ada hari ini kita harus mempersiapkan pemimpin } \\
\text { akan datang dengan menilai beberapa aspek seperti : panggilan, kualitas } \\
\text { seseorang dan reputasi dia. }\end{array}$ \\
\hline 3 & $\begin{array}{l}\text { Perlu adanya perancangan yang baik untuk mempersiapkan legacy akan } \\
\text { datang. Oleh sebab itu perlu mengenal pasti orang-orang yang sesuai demi } \\
\text { memastikan kesinambungan kepemimpinan BEM. }\end{array}$ \\
\hline 4 & $\begin{array}{l}\text { Ini adalah hal yang perlu dilakukan dengan menilai calon pemimpin yang } \\
\text { kompetensi dan mempersiapkan untuk menjadi pemimpin akan datang }\end{array}$ \\
\hline 5 & Mengenali jemaat yang berpotensi secara teknikal \\
\hline 6 & Seorang pemimpin haruslah berkarisma. \\
\hline
\end{tabular}

Berdasarkan hasil wawancara dengan informan mengenai pertanyaan bagaimanakah pemimpin hari ini dapat melakukan perubahan di dalam kepemimpinannya? Hasil analisis peneliti melalui jawaban informan semua sependapat bahwa BEM hari ini memerlukan seorang pemimpin yang kompetensi untuk membawa perubahan di dalam kepemimpinan BEM pada masa akan datang. Kompetensi itu terlihat melalui upaya seorang pemimpin untuk menganalisis situasi masa kini bagi mempersiapkan masa depan. Karenanya, untuk mendapatkan pemimpin yang berkompeten pemimpin hari ini perlu mengidentifikasi pemimpin muda yang ada untuk dipersiapkan.

\section{Pembahasan}

Berdasarkan pengolahan deskriptif, analisis, interpretasi data dan pengolahan data statistik yang telah diuraikan, maka penelitian ini memberikan hasil sebagai berikut:

\section{Ciri-ciri Pemimpin Transformasional}

Pemimpin di berbagai bidang baik pendidikan, ekonomi, undang-undang, politik, kesehatan dan sebagainya pasti memerlukan beberapa kualifikasi yang diharapkan. Ciri-ciri 
pemimpin yang transformasional adalah pemimpin yang hidup benar di mata Tuhan. ${ }^{6}$ Meskipun menurut para informan ada berbagai jawaban, namun jika dicermati ternyata yang menjadi prinsip dari kepemimpinan Kristen adalah pemimpin yang mempunyai kehidupan rohani yang baik. Prinsip ini selaras dengan prinsip Alkitab yang menjelaskan: "Benarlah perkataan ini: 'Orang yang menghendaki jabatan penilik jemaat menginginkan pekerjaan yang indah.' Karena itu penilik jemaat haruslah seorang yang tak bercacat, suami dari satu isteri, dapat menahan diri, bijaksana, sopan, suka memberi tumpangan, cakap mengajar orang." 7

Jikalau seorang ingin menjadi "penilik" jemaat (Yun. episkopos, yaitu seorang yang mempunyai kewajiban pastoral; gembala), dia menginginkan pekerjaan yang indah (1Tim 3:1). Akan tetapi, keinginan orang itu harus ditetapkan oleh Firman Allah (1Tim 3:1-10; 4:12) dan gereja (1Tim 3:10), karena Allah telah menetapkan beberapa syarat tertentu bagi gereja. Setiap panggilan yang diakui dari Allah untuk melakukan pekerjaan pastoral harus diuji oleh anggota jemaat menurut standar alkitabiah yang terdapat dalam 1Tim 3:1-13;

Allah telah menetapkan standar bahwa seorang penilik jemaat harus orang percaya dan setia kepada Yesus Kristus dan melakukan perintah-perintah-Nya sehingga menjadi teladan bagi jemaat baik dalam hal kesetiaan, kebenaran, kejujuran dan kekudusan. Iman dan gaya hidup Kristen harus nyata dalam kehidupannya sehingga dapat ditiru jemaat. ${ }^{8}$ Salah satu tugas utama dari seorang penilik ialah memberi makan kepada domba-domba Allah dengan mengajarkan Firman Allah. Seorang penilik harus selalu ingat bahwa kawanan domba yang diberikan kepada mereka adalah umat Allah sendiri yang telah dibeli untuk diriNya dengan darah Anak-Nya yang mahal. Bukan pekerjaan mudah menjadi seorang penilik jemaat.

\section{Role Model Kepemimpinan}

Kualifikasi seorang pemimpin yang Alkitabiah adalah dasar untuk menentukan kepemimpinan yang memiliki aturan yang akan dapat menjadi role model, bukan saja bagi komunitas Kristen namun juga kepada dunia sesuai dengan panggilan gereja sebagai umat

\footnotetext{
${ }^{6}$ Suhadi Suhadi dan Yonatan Alex Arifianto, "Pemimpin Kristen Sebagai Agen Perubahan di Era Milenial," EDULEAD: Journal of Christian Education and Leadership 1, no. 2 (2020): 129-147; Dapot Tua Simanjuntak dan Joseph Christ Santo, "Kepemimpinan Gembala Sidang dalam Meningkatkan Pertumbuhan Jemaat: Sebuah Refleksi 1 Petrus 5," Paria 6, no. 1 (2019): 66-76.

${ }^{7}$ Alkitab Terjemahan Baru (Jakarta: Lembaga Alkitab Indonesia, 2008), 1Tim. 3:1-2.

${ }^{8}$ Ezra Tari, Ermin Alperiana Mosooli, dan Elsye Evasolina Tulaka, "Kepemimpinan Kristen Berdasarkan 1 Timotius 3:1-7," Jurnal Teruna Bhakti 2, no. 1 (2019): 15-21.
} 
Allah. ${ }^{9}$ Nas 2 Raja-Raja 18:5 "Ia percaya kepada TUHAN, Allah Israel, dan di antara semua raja-raja Yehuda, baik yang sesudah dia maupun yang sebelumnya, tidak ada lagi yang sama seperti dia." Teks ini menjelaskan kepada kita bagaimana kehidupan Raja Hizkia sebagai sosok pemimpin yang menjadi model dalam segala abad. Hasil penelitian yang dilakukan melalui wawancara memberi peneguhan di mana 4 dari 6 informan menjelaskan bahwa karakter pemimpin yang menjadi model adalah pemimpin yang tunduk kepada Tuhan sebagai sumber otoritas.

Dalam 1 Korintus 11:1 Paulus memberi tahu kita bahwa pemimpin harus menjadi role model dengan menulis, "Ikuti teladanku, seperti aku mengikuti teladan Kristus." ${ }^{10}$ Integritas adalah kejujuran karakter, yaitu kejujuran yang sejalan dengan Firman Tuhan. Bagi seorang pemimpin yang menjadi role model, perkataan mereka harus sejalan dengan perbuatan. Saat mereka mengatakan akan melakukan sesuatu, mereka haruslah melakukannya. Kegagalan di dalam memimpin sangat ditentukan oleh faktor karakter seorang pemimpin sejauh dia mampu menjadi role model kepada orang-orang yang dipimpin, dalam konteks BEM Sarawak adalah jemaat yang sedang dilayani. Setiap pemimpin dituntut untuk menjadi role model, dan penulis yakin bahwa sebagai pemimpin Kristen, Yesuslah menjadi role model kita supaya boleh menjadi role model bagi jemaat. Yakob Tomattala menjelaskan: Memimpin seperti Yesus adalah kepemimpinan yang berbasis kehidupan-Nya. Kebenaran tentang kepemimpinan Yesus Kristus ini merujuk kepada hakikat hidup, cara hidup, sifat, sikap dan kebiasaan-Nya yang ekselen yang didemonstrasikan melalui pikiran, perasaan, kehendak". ${ }^{11}$

Pemimpin yang mampu menjadi role model akan mudah untuk membawa orangorang yang dipimpin berkerja sama dalam melaksanakan tugas dalam kepemimpinan. Hari ini diperlukan seorang pemimpin yang mampu memberi teladan kepemimpinan ${ }^{12}$ yang berintegritas tinggi, bekerja, melayani dengan hati yang bersih dan membangun budaya kerja yang jujur serta menempatkan kebenaran Firman Tuhan sebagai ukuran dari setiap kebijakan pemimpin.

\footnotetext{
${ }^{9}$ Iksantoro Iksantoro, "Potret Pemimpin Kristen Sebagai Sumber Daya Manusia Unggul Menurut Kitab Titus," Jurnal Teologi Berita Hidup 2, no. 1 (2019): 36-47.

${ }^{10}$ Render Luwis, "Keteladanan Kepemimpinan Rasul Paulus sebagai Role Model dalam Pengembangan Sumber Daya Manusia Berdasarkan Efesus 4:1-16 di Gereja Bahagian Bahasa Melayu di Negara Brunei Darussalam,” Jurnal Teologi Berita Hidup 2, no. 2 (2020): 142-153.

${ }^{11}$ Yakob Tomatala, Memimpin Seperti Yesus Kritus (Jakarta: YT Leadership Foundation, 2013), 11.

12 Joseph Christ Santo dan Dapot Tua Simanjuntak, "Pengaruh Keteladanan Hidup Gembala Sidang terhadap Pertumbuhan Gereja," Kharismata: Jurnal Teologi Pantekosta 2, no. 1 (2019): 28-41.
} 


\section{Pemimpin Bervisi}

Pemimpin dipilih dan diutus oleh Allah untuk menjadi pemimpin yang memiliki visi dan misi yang jelas, yakni menyejahterakan jemaat. Itu berarti pemimpin harus tahu dengan jelas apa visi dan misi Allah bagi umat-Nya. Belajar dari Raja Hizkia bagaimana Allah menetapkan Dia untuk melakukan pemulihan bagi umat Allah. Visi tersebut disertai degan tindakan nyata Hizkia untuk memurnikan penyembahan umat Allah.

Hal inilah yang seharunya dilakukan oleh semua pemimpin gereja khusus di dalam BEM Sarawak. Pemimpin perlu tahu akan di bawah ke mana warga jemaat yang dipimpinnya. Arah dan tujuan harus jelas, agar visi yang ideal itu dapat terwujud, maka perlunya mengembangkan dan mewujudkan visi serta tujuan jangka panjang dan jangka pendek yang hendak dicapai. Misi perlulah yang konkret demi sebuah perubahan ke arah pencapaian visi Allah. Perlu diingat bahwa visi dan misi seorang pemimpin Gereja harus bersifat kontekstual, kini, dan bersifat kekinian sesuai dengan pergumulan akan keperluan dan kepentingan kehidupan warga jemaat. Pemimpin hendaklah menjelaskan dan mengucapkan kata-kata dengan jelas tentang sasaran serta arah yang ingin dicapai sesuai dengan Visi organisasi. Dalam hal ini pemimpin perlu secara berulang-ulang mengkomunikasikan visi agar jemaat menangkap visi dengan tepat.

BEM Sarawak melalui "way forward" telah menetapkan visi untuk menjadi "Gereja Yang Meneroka" (meneroka = mengeksplorasi) melalui lima misi yang dilaksanakan dalam jangka waktu lima belas tahun ke depan. Menilai visi dan misi BEM di atas, dapat dirumuskan bahwa visi dan misi seorang pemimpin haruslah mencerminkan visi dan misi Allah, yakni membebaskan" dan "menyelamatkan" dalam rangka memelihara kehidupan manusia sebagai citra Allah, mempraktikkan nilai-nilai kebaikan, keadilan dan kebenaran. Yakob Tomatala menjelaskan, "visi yang adalah keinginan suci memberikan kemampuan untuk memahami kehendak Allah dan melihat ke depan akan apa yang akan terjadi."13

Namun perlu diperhatikan oleh pemimpin agar setiap visi dan misi perlu dievaluasi dalam satu-satu masa bagi memastikan organisasi tetap berada di "track" yang tepat di dalam melaksanakan agenda Allah. Jika tidak demikian maka visi dan misi hanya sebagai hiasan yang membuat menarik setiap halaman kertas kosong pada setiap persidangan. Visi adalah harta yang terpendam yang sering diabaikan oleh banyak orang. Para rohaniwan, pemimpin gereja, yayasan maupun sekuler tidak dapat menjalankan tugasnya dengan baik tanpa visi.

${ }^{13}$ Yakob Tomatala, Anda Juga Bisa Menjadi Pemimpin Visioner (Jakarta: YT Leadership Foundation, 2005), 46. 
Seperti yang dikatakan oleh Amsal 29:18 itu benar: "Without vision my people perish". ${ }^{14}$ Ada banyak pemimpin dan individu sudah mengalami kegagalan karena tidak mempunyai visi. Tanpa visi adalah tanpa masa depan karena visi selalu melihat masa depan dengan perspektif optimisme. Pesimisme terjadi bukan karena seseorang tidak sanggup, tapi karena tidak punya visi. Oleh sebab itu marilah kita mengerti pentingnya visi itu dan berusaha untuk memilikinya. Usahakanlah agar segala rencana dimulai dengan visi. Visi yang terbesar bagi orang percaya adalah menjadikan segala bangsa itu murid-Nya. Apa pun profesinya, amanat agung yang merupakan visi misi utama Allah Tritunggal harus digenapi. Visi ini akan diikuti kuasa Allah yang menyertai.

Setiap orang percaya diberikan karunia untuk mengembangkan diri dengan visi di tangan. Visi adalah bekal dan pengharapan diberikan kepada kita melalui anugerah Yesus Kristus. Dia telah menggenapi visi Bapa yakni menebus dosa manusia melalui jalan salib. Oleh sebab itu visi harus dimiliki, dan tidak memasuki sesuatu pelayanan tanpa visi. Visi akan membuat semua pelayanan berbuah dan nama Tuhan dipermuliakan.

\section{Pemimpin Kompeten}

Semua informan sependapat bahwa BEM Sarawak ke depan memerlukan seorang pemimpin yang berkarisma atau memiliki kompetensi. Selain faktor perkembangan dan kemajuan sekarang, kompetensi seorang pemimpin di dalam BEM Sarawak perlu bagi memastikan terjadinya perubahan dalam pola kepemimpinan BEM akan datang.

Seorang pemimpin perlu memiliki sebanyak mungkin kompetensi, untuk menjadi pemimpin di era yang disebut relativisme dan individual subjektivisme. Jika dibanding Era Modern yang lalu, masih ada kebenaran yang mutlak. Namun di Era Postmodern sekarang ini, telah berubah menjadi absolute relativism dan individual subjectivism (No-Standard). Tidak ada lagi kebenaran yang mutlak dan universal, akhirnya dunia sedang menjadi kacau. Pragmatisme menjadi kecenderungan, sekularisme menguasai masyarakat dunia dan juga Gereja. Situasi dan kondisi ini menuntut sang pemimpin memiliki kemampuan yang luar biasa, namun tidak semua pimpin akan memiliki semuanya. Menurut pengamatan, terdapat beberapa kompetensi penting yang perlu, yaitu pengetahuan, kemahiran atau skill, komunikasi, dan kemampuan mengatasi konflik. Secara khusus, sebagai pemimpin Kristen maka hal yang sangat dituntut adalah agar pemimpin memiliki pengetahuan teologi yang

${ }^{14}$ The Holy Bible: King James Version, Electronic Edition of the 1900 Authorized Version. (Bellingham, WA: Logos Research Systems, Inc., 2009), Pr. 29:18. 
benar. Stevri Indra Lumintang merumuskan bahwa pentingnya pengetahuan teologi sebagai berikut: ${ }^{15}$

1. Memberi petunjuk untuk hal yang terutama dan tertinggi.

2. Menghidupkan ilmu pengetahuan dan menjawab blind spot-nya.

3. Teologi menuntun dan mendorong pembacaan Alkitab.

4. Teologi mendasari semua pemahaman dan perbuatan orang Kristen.

5. Teologi menguji semua dasar, keyakinan dan pengajaran Kristen

6. Teologi mengonstruksi semua keyakinan dan pengajaran Kristen.

7. Teologi memperdalam pemahaman, mempercepat pertumbuhan iman dan memperkaya karakter orang percaya

8. Teologi memperlengkapi dan membentengi orang percaya

9. Teologi memurnikan semua motif hidup dan pelayanan orang percaya

10. Teologi memaknai pengalaman baik dan buruk orang percaya

11. Teologi mendinamiskan dan memaksimalkan hidup dan pelayanan

\section{Implikasi Hasil Penelitian}

Hasil penelitian ini diharapkan bisa membantu untuk memberi masukan kepada kepemimpinan BEM Sarawak di setiap tingkat dan khususnya di tingkat MU dan ME. Pengamatan dari hasil wawancara baik melalui tatap muka dan menggunakan media Zoom, peneliti mendapati bahwa pimpinan tidak memberi perhatian kepada usaha untuk meninjau kembali sistem kepemimpinan yang digunakan. Keadaan ini bisa saja menyebabkan pemimpin yang ada secara tidak langsung akan terorganisasi dengan sistem yang ada.

Seharusnya dengan adanya pengalaman pelayanan yang dimiliki oleh para pemimpin yang ada, memberi mereka kelebihan dan mempunyai cukup waktu untuk mengevaluasi pencapaian mereka supaya mampu meningkatkan berbagai upaya transformasional di dalam BEM Sarawak. Para pimpinan sebaiknya lebih memberikan perhatian kepada usaha untuk memantapkan lagi sistem kepemimpinan, terutama yang berkaitan dengan fungsi utama BEM sebagai sebuah denominasi Injili. Apabila jemaat memahami fungsi utama gereja BEM sesuai dengan Amanat Agung maka kesadaran untuk lebih bertanggung jawab akan meningkatkan pelibatan jemaat.

Pengamatan dari hasil penelitian ditemukan bahwa BEM Sarawak perlu berubah sesuai dengan keadaan sekarang. Oleh itu diharapkan agar adanya para pemimpin yang sungguh-sungguh dipakai Tuhan untuk dapat merumuskan apakah perubahan yang perlu

\footnotetext{
${ }^{15}$ Stevri Indra Lumintang, Teologi Reformasi Gereja Abad ke- 21 (Jakarta, 2019).
} 
dilakukan oleh BEM Sarawak ke depan. Jika tidak demikian maka BEM Sarawak akan menjadi mandek.

\section{Keterbatasan Penelitian}

Penelitian ini memiliki beberapa keterbatasan antara lain: Pusat BEM Sarawak tidak memiliki sumber-sumber yang cukup untuk dijadikan data penelitian. Oleh sebab itu peneliti hanya melakukan wawancara kepada barisan kepemimpinan tertinggi. Dari jumlah empat orang anggota ME, satu orang anggota tidak bersedia untuk diadakan wawancara. Tiga orang informan merupakan anggota MU yang sedang aktif dan memiliki perbedaan latar belakang sosial, budaya dan karier. Ini sesuai dengan keunikan BEM Sarawak sebagai sebuah denominasi yang bersifat majemuk.

\section{KESIMPULAN}

Dari data yang didapatkan dan analisis yang telah dilakukan dalam penelitian ini maka yang dapat disimpulkan adalah sebagai berikut:

Penelitian ini membuktikan perlunya pemimpin BEM melakukan perubahan. Perubahan yang dilakukan menentukan perkembangan dan kemajuan BEM Sarawak pada masa akan datang.

Penelitian ini membuktikan adanya pengaruh positif antara ciri-ciri seorang pemimpin dengan karakternya (penelitian pada MU dan ME BEM Sarawak). Dengan memiliki pengalaman pelayanan yang luas menggambarkan bahwa mereka adalah pemimpin yang teruji dan terbukti.

Penelitian ini membuktikan adanya pengaruh negatif, apabila ada pemimpin yang tidak mau melakukan perubahan, maka BEM Sarawak akan tidak relevan menghadapi era mendatang.

\section{Rekomendasi Penelitian Lanjutan}

Penelitian ini akan lebih berguna apabila hasil dari penelitian ini digunakan untuk suatu usulan perbaikan, sehingga penelitian-penelitian berikutnya dapat menjadi lebih baik dan dapat memperbaiki keterbatasan-keterbatasan dari penelitian ini. Selain itu penelitian ini dilakukan secara kualitatif dengan pendekatan fenomenologi, terbuka peluang untuk dilakukan penelitian lanjutan dengan metode kuantitatif dengan pendekatan konfirmatori untuk memberikan hasil yang lebih signifikan. 


\section{REFERENSI}

Blanchard, Ken, dan Phil Hodges. Lead Like Jesus. Tangerang: Visi Media, 2006.

Iksantoro Iksantoro. "Potret Pemimpin Kristen Sebagai Sumber Daya Manusia Unggul Menurut Kitab Titus." Jurnal Teologi Berita Hidup 2, no. 1 (2019): 36-47.

Lumintang, Stevri Indra. Teologi Reformasi Gereja Abad ke- 21. Jakarta, 2019.

Luwis, Render. "Keteladanan Kepemimpinan Rasul Paulus sebagai Role Model dalam Pengembangan Sumber Daya Manusia Berdasarkan Efesus 4:1-16 di Gereja Bahagian Bahasa Melayu di Negara Brunei Darussalam.” Jurnal Teologi Berita Hidup 2, no. 2 (2020): 142-153.

Santo, Joseph Christ, dan Dapot Tua Simanjuntak. "Pengaruh Keteladanan Hidup Gembala Sidang terhadap Pertumbuhan Gereja." Kharismata: Jurnal Teologi Pantekosta 2, no. 1 (2019): 28-41.

Scazzero, Peter. The Emotionallly Healthy Leader. Surabaya: Perkantas, 2018.

Simanjuntak, Dapot Tua, dan Joseph Christ Santo. "Kepemimpinan Gembala Sidang dalam Meningkatkan Pertumbuhan Jemaat: Sebuah Refleksi 1 Petrus 5.” Paria 6, no. 1 (2019): 66-76.

Suhadi, Suhadi, dan Yonatan Alex Arifianto. "Pemimpin Kristen Sebagai Agen Perubahan di Era Milenial." EDULEAD: Journal of Christian Education and Leadership 1, no. 2 (2020): 129-147.

Tari, Ezra, Ermin Alperiana Mosooli, dan Elsye Evasolina Tulaka. "Kepemimpinan Kristen Berdasarkan 1 Timotius 3:1-7.” Jurnal Teruna Bhakti 2, no. 1 (2019): 15-21.

Tomatala, Yakob. Anda Juga Bisa Menjadi Pemimpin Visioner. Jakarta: YT Leadership Foundation, 2005.

—. Memimpin Seperti Yesus Kritus. Jakarta: YT Leadership Foundation, 2013.

- Mencari Format Kepemimpinan Gereja yang Kontekstual di Indonesia. Jakarta: YT Leadership Foundation, 2002.

Alkitab Terjemahan Baru. Jakarta: Lembaga Alkitab Indonesia, 2008.

"Borneo Evangelical Mission." Last modified 2019. Diakses Januari 31, 2021. https://en.wikipedia.org/wiki/Borneo_Evangelical_Mission.

The Holy Bible: King James Version, Electronic Edition of the 1900 Authorized Version. Bellingham, WA: Logos Research Systems, Inc., 2009. 